\title{
Developing Undergraduate Research in Japanese Medical Education
}

\begin{abstract}
In Japanese medical education, undergraduate research was first introduced in the 1960s, and currently 69 out of 80 medical schools surveyed (86 percent) have incorporated research-oriented education into the curriculum (Mori 1991; Association of Japanese Medical Colleges 2014). For over 50 years, however, undergraduate research generally has tended to be a springboard for basic medical scientists or content experts-students interested in pursuing an academic career and advancing knowledge. Now, however, the World Federation for Medical Education's global standards for basic medical education stress the cultivation of students' critical-thinking skills through research as an important component of an educational program (World Federation for Medical Education 2012). This article describes the recent educational practice of undergraduate research at a Japanese medical school and the effects on students' perceptions of the research and approaches to learning (Imafuku et al. 2015). Then we emphasize the necessity of using a research-skill development framework (Willison and O'Regan 2007) and, based on our pedagogical practices and research findings, discuss the potential of inter-university collaboration and interdisciplinary undergraduate research.
\end{abstract}

In the late 19th century, the Meiji government, which abolished the samurai feudal political system and adopted a constitutional monarchy, started to Westernize the school system and establish imperial research universities. The identity of Japanese universities was highly influenced by von Humboldt's conception of higher education, which emphasized the connection between learning and research. Since then, Japanese research universities have focused particularly on the enhancement of undergraduates' academic and professional knowledge as the chief desired learning outcomes. However, in response to complicated issues raised in modern Japanese society, such as information overload, globalization, and an aging society, undergraduates need to be educated not as "storehouses of knowledge" but as lifelong learners.

The Central Council for Education of the Japanese Government (2012) has also emphasized the necessity of a qualitative change in undergraduate education, recognizing the importance of further facilitating Japanese students' self-directed learning. This reassessment of educational strategies in Japanese higher education was motivated by the results of two national surveys conducted in 2007 on undergraduates' educational engagement in Japan and the U.S. (National Survey of Student Engagement 2007; University of Tokyo 2007). For instance, these data showed that 58.4 percent of first-year students in the U.S. spent more than 11 hours per week preparing for class, whereas only 14.8 percent of Japanese first-year students put in the same amount of preparation.

As part of the shift from an instructional paradigm to a learning paradigm (Barr and Tagg 1995), a variety of strategies and approaches to promoting students' active learning now are under discussion among academics and support staff in Japanese higher education. For instance, project/ problem-based learning, flipped classrooms and blended learning have been employed as innovative pedagogies in some institutions (Kitazawa, Nagai and Ueno 2008; Shigeta 2014; Yamauchi 2014). Nevertheless, the integration of undergraduate research into the curriculum has not been widely achieved in Japanese higher education even though research-based teaching has been used for more than 50 years in Japanese medical education (Mori 1991). Here we provide a glimpse into students' research experiences in Japanese medical education in the hope that they might encourage deep reflection on the state of undergraduate research in the U.S. as well as other countries.

\section{Japanese Medical Education}

As of 2016 there are 81 medical schools in Japan. The Japanese medical education system differs from that of the U.S. in many respects. For instance, as summarized by Kuwabara et al. (2015), medical school in Japan is a six-year undergraduate program, rather than the U.S. model of a four-year program after completion of undergraduate work (Figure 1). The Japanese program basically consists of general education (the first year), pre-clinical studies (the middle two-and-a-half to three years), and clinical clerkships and preparation for national licensing examinations (the last two years). Before entry into clinical study or a clerkship, students are required to take computer-based testing for medical knowledge and an objective structured clinical examination for clinical skills.

The Japanese national licensing examination is a high-stakes test, in which candidates complete 500 multiple-choice 
Figure 1. Medical Education in Japan and the U.S.

Japanese Medical Education

\begin{tabular}{|c|c|c|c|c|c|c|}
\hline \multirow{2}{*}{$\begin{array}{l}\text { Secondary } \\
\text { education }\end{array}$} & \multicolumn{3}{|c|}{$\begin{array}{l}\text { Medical school - } 6 \text { years } \\
\text { (Undergraduate program) }\end{array}$} & \multirow{2}{*}{$\begin{array}{c}\text { Residency } \\
\text { (foundation) } \\
2 \text { years }\end{array}$} & \multirow[b]{2}{*}{$\begin{array}{c}\text { Senior residency } \\
\text { (specialist training) } \\
3-5 \text { years }\end{array}$} & \multirow[t]{2}{*}{$\begin{array}{c}\text { Practitioner } \\
\text { Hospitalist }\end{array}$} \\
\hline & $\begin{array}{l}\text { General } \\
\text { education } \\
1-1.5 \text { years }\end{array}$ & $\begin{array}{l}\text { Pre-clinical } \\
\text { study } \\
2.5-3 \text { years }\end{array}$ & $\begin{array}{l}\text { Clinical study/ } \\
\text { clerkships } \\
2 \text { years }\end{array}$ & & & \\
\hline & & $\begin{array}{l}\text { Computer-Bas } \\
\text { Objective Stru }\end{array}$ & Clinical Exam & $N$ & & \\
\hline
\end{tabular}

\section{U.S. Medical Education}

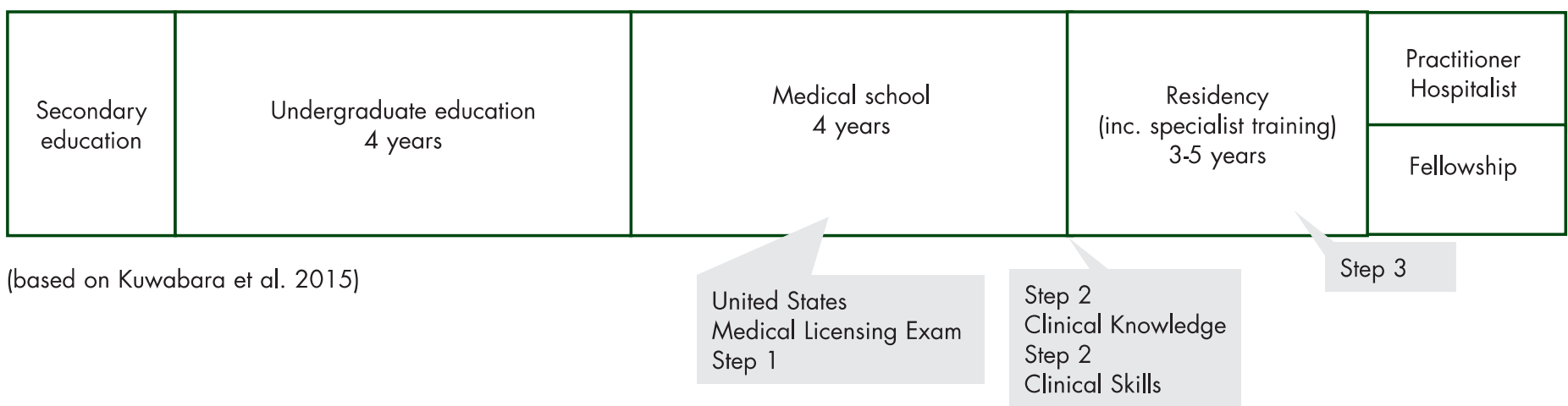

questions over three days. Suzuki, Gibbs, and Fujisaki (2008) explained that the final year of medical school is often dominated by preparation for the exam. On the other hand, the United States Medical Licensing Exam is a three-stage examination focused on basic medical sciences (Step 1), clinical knowledge and skills (Step 2), and comprehensive knowledge essential to the independent practice of medicine and a demonstration of evidence-based medicine (Step 3). The Association of Japanese Medical Colleges (AJMC) reported in 2014 that the total length of clinical clerkships averaged about 54 weeks (from 40 to 78 weeks), which is shorter than in American medical schools (at least 72 weeks).

It is important for medical educators to utilize educational approaches that can more effectively encourage a deep approach to learning and foster students' self-directed learning skills. To date, problem-based learning (PBL) and team-based learning (TBL) have been employed as interactive educational methods to prompt students' active learning in Japanese medical education. A number of studies have explored medical students' learning outcomes and processes in PBL or TBL (e.g., Imafuku 2012; Imafuku et al. 2014; Ohtsuki and Matsui 2014). Japanese medical educators are now taking notice of the flipped classroom as a new educational strategy (e.g., Nishiya, Sumitani and Okada 2014).

\section{Undergraduate Research in Japanese Medical Education}

As noted above, students' research activity has often been viewed not as a pedagogical approach but rather as an opportunity for academic output. In Japanese medical education, research-based teaching was originally integrated into the curriculum in the 1960 s for final-year students who wanted to become basic medical scientists or content experts. Until recently, the focus of research-based teaching has been heavily focused on training researchers. As the importance of facilitating medical students' active learning is recognized, some medical schools have started to view this research-based teaching as an educational opportunity. They see engaging students in research and inquiry as helping cultivate the generic skills necessary for continuing professional development. 
A global trend in medical education is also influential in this paradigm shift in Japan. Laidlaw et al. (2012) argues that research activity is a powerful way to enhance medical students' basic skills and attitudes toward continuing professional development. In particular, integration of elements of evidence-based medicine into the undergraduate curriculum and development of research skills now are seen as increasingly important. For instance, the cultivation of students' critical-thinking skills through research experiences is described as an important component of the undergraduate educational program in the World Federation for Medical Education's global standards for basic medical education (World Federation for Medical Education 2012).

In a 2014 study, 69 out of the 80 medical schools then existing in Japan have incorporated undergraduate research into the curriculum (AJMC 2014). There are different approaches toward research-based teaching in terms of the educational purposes (training a researcher or enhancing students' learning through research); duration of the research course (ranging from three to 45 weeks); course types (compulsory or elective); and assessment methods.

Most Japanese medical schools have noted that engaging undergraduate medical students in research and inquiry is an important part of the curriculum. As a survey of the AJMC shows, the number of Japanese medical schools that offer undergraduate research as a compulsory course is increasing annually, with 48 medical schools requiring such a course in 2009, 59 in 2011, and 63 in 2013. The AJMC reported that 60 out of 80 Japanese medical schools implemented undergraduate research in the pre-clinical study periods (that is, in second-, third- or fourth-year programs). This finding suggests that undergraduate research in pre-clinical study can be an opportunity to promote students' fundamental understanding of the research process and commitment to lifelong learning as health professionals.

The AJMC (2014) describes the several ways of assessing students' research experiences and outcomes in Japanese medical schools. Summative assessments are basically achieved through evaluation of research papers/written assignments (25 schools) and/or academic presentations (35 schools). A learning portfolio is utilized as a formative assessment in two schools. Another two schools do not conduct any assessment of students' undergraduate research.

In Japanese medical education, there is a growing belief that students' engagement in research activity has the potential to enhance their active/reflective learning skills and their capacity for critical appraisal, in addition to helping students develop research skills. Thus, research activity as an educa- tional practice has been increasingly employed in medical schools, as described above. However, little is known about medical students' actual experiences of learning and their perceptions of undergraduate research. In the following section, we briefly describe our recent educational practice and students' learning experiences in undergraduate research.

\section{A Mandatory Research Course}

Gifu University School of Medicine offers a mandatory course, Research Experience, in which all third-year students (about 110 every year) select one 10-week subject or two five-week subjects from 26 research themes outlined in basic, social or clinical medical sciences. This course encourages students to actively pursue a research theme of interest in a scientific manner. It primarily involves project work, and there are no other classes during the "research" weeks to detract from students' learning experiences. At the end of the final week students are required to give poster and oral group presentations in front of all third-year students and faculty.

Research into medical education is one of the 26 themes in the Research Experience course. Every year about seven students select the subject of medical education. Class meetings from two to three hours are typically scheduled three days a week, and the rest of class time in a week ( 21 hours) is allotted to self-directed research activity. In each class, students are encouraged to discuss research design and to give progress reports. The research themes on medical education undertaken by the students in the last three years are:

Work-life balance and professionalism in a doctor: A view from medical students (2015)

- Gender differences in medical students' perceptions of career path, household affairs, and childcare (2014)

- Medical students' participation in problem-based learning tutorials (2013)

- Medical students' perceptions of community medicine (2013)

Students have conducted qualitative and/or quantitative studies to explore medical students' behavior in the classroom and their perceptions of medical education, doctors, and healthcare.

Drawing on a framework outlining research-skill development (Willison and O'Regan 2007), tutors' roles in undergraduate research on medical education were defined. The educators participated as mentors who encouraged students to autonomously conduct a research project. Students' in- 
dependent research was shaped by tutors' scaffolds or guides. The extent of the students' autonomy was basically set as "scaffolded research" (level 3) or "student-initiated research" (level 4). An overview of tutors' roles at each stage of research is given in Table 1.

Tutors took on the role of facilitators to promote students' learning through research. However, as Table 1 shows, the tutors did the statistical analysis of the questionnaire survey using software in week 8 of the course. Students were encouraged to focus on interpreting the statistical data analyzed by their tutors rather than learning how to use the software.

As shown in week 5 in Table 1, a web conference on medical education research has been held with Kagawa University Medical Education Center since 2014. Communicating with students who were conducting research in the same field at other universities was designed to stimulate their participation in the subsequent research activities. Further, through the conference it was felt that the students could learn the importance of intelligible and logical explanation of their own research by experiencing other academic presentations. Thus, we believe inter-university educational collaboration has the potential to enhance students' learning in undergraduate research.

One author, Imafuku, and colleagues in 2015 conducted a qualitative study to examine how medical students' perceptions of research and learning changed during their undergraduate course on research in medical education. Data analysis of interviews with 14 students showed that at the beginning of the course, the majority of students expressed a relatively narrow definition of research, focusing on its content and outcomes. End-of-course reflections indicated increased attention to re-
Table 1. Students' Research and Tutors' Roles in a Medical Education Research Course

\begin{tabular}{|c|c|c|}
\hline & $\begin{array}{l}\text { Facet of research (based on } \\
\text { Willison and O'Regan 2007) }\end{array}$ & Tutors' role \\
\hline Week 1 & $\begin{array}{l}\text { [Embark \& Clarify] } \\
\text { Research design and research } \\
\text { questions }\end{array}$ & $\begin{array}{l}\checkmark \text { Give guidelines for generating RQs in terms of feasi- } \\
\text { bility, novelty, ethicality, clarity, and originality }\end{array}$ \\
\hline Week 2 & $\begin{array}{l}\text { [Embark \& Clarify] } \\
\text { Information searching } \\
\text { Reviewing related literature }\end{array}$ & $\begin{array}{l}\checkmark \text { Give overview of the purpose of reviewing related } \\
\text { literature } \\
\checkmark \text { Give tips for information searching, such as data- } \\
\text { base, use of keywords and source types (primary or } \\
\text { secondary source) }\end{array}$ \\
\hline Week 3 & $\begin{array}{l}\text { [Find \& Generate] } \\
\text { Preparation for data collection } \\
\text { (Qualitative study) }\end{array}$ & $\begin{array}{l}\checkmark \text { Give an overview of research methodologies and } \\
\text { approaches (e.g., qualitative and qualitative studies) } \\
\checkmark \text { Advise on participant sampling in research and set- } \\
\text { ting interview questions }\end{array}$ \\
\hline Week 4 & $\begin{array}{l}\text { [Find \& Generate] } \\
\text { [Organize \& Manage] } \\
\text { Data collection }\end{array}$ & $\begin{array}{l}\checkmark \text { Suggest a way of eliciting information in an interview } \\
\text { setting }\end{array}$ \\
\hline \multirow[t]{2}{*}{ Week 5} & $\begin{array}{l}\text { [Analyze \& Synthesize] } \\
\text { Data analysis }\end{array}$ & $\begin{array}{l}\checkmark \text { Explain a qualitative analysis procedure, such as the- } \\
\text { matic analysis }\end{array}$ \\
\hline & $\begin{array}{l}\text { [Communicate \& Apply] } \\
\text { A web conference with Kagawa } \\
\text { University Medical Education } \\
\text { Center }\end{array}$ & $\begin{array}{l}\checkmark \text { Arrange the web conference } \\
\checkmark \text { Give feedback on each presentation }\end{array}$ \\
\hline Week 6 & $\begin{array}{l}\text { [Find \& Generate] } \\
\text { Preparation for data collection } \\
\text { (Quantitative study) }\end{array}$ & $\checkmark$ Suggest questionnaire design and types of questions \\
\hline Week 7 & $\begin{array}{l}\text { [Find \& Generate] } \\
\text { [Organize \& Manage] } \\
\text { Data collection }\end{array}$ & $\begin{array}{l}\checkmark \text { Support the recruitment of research participants and } \\
\text { the implementation of questionnaire survey } \\
\checkmark \text { Explain making a transcript of interview data }\end{array}$ \\
\hline Week 8 & $\begin{array}{l}\text { [Analyze \& Synthesize] } \\
\text { Data analysis and interpretation } \\
\text { of data }\end{array}$ & $\begin{array}{l}\checkmark \text { Use SPSS software and provide the results of statisti- } \\
\text { cal data analysis } \\
\checkmark \text { Assist students in interpreting the statistical data anal- } \\
\text { ysis }\end{array}$ \\
\hline Week 9 & $\begin{array}{l}\text { [Analyze \& Synthesize] } \\
\text { Data analysis } \\
\text { Preparation for academic presen- } \\
\text { tations }\end{array}$ & $\begin{array}{l}\checkmark \text { Give feedback on interpretation of statistical data } \\
\text { analysis } \\
\checkmark \text { Explain what good poster and oral presentations are }\end{array}$ \\
\hline $\begin{array}{l}\text { Week } \\
10\end{array}$ & $\begin{array}{l}\text { [Communicate \& Apply] } \\
\text { Poster and oral presentations at } \\
\text { the school }\end{array}$ & $\checkmark$ Assess students' presentation \\
\hline
\end{tabular}

search processes including self-initiated learning activity, collaboration, and processes of knowledge construction (Table 2). This study shows that students' awareness of linking learning and research indicated an epistemological change leading them to take a deep approach to learning in undergraduate research. Students' revised perceptions of research included understanding that it requires an inquiring mind, 
Table 2. Changes in Students' Perceptions of Undergraduate Research

Beginning of Undergraduate Research in Week 2

\begin{tabular}{|c|c|c|}
\hline & $\begin{array}{l}\text { Research } \\
\text { is..... }\end{array}$ & Verbatim examples \\
\hline \multirow{6}{*}{ 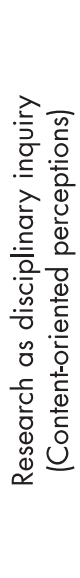 } & $\begin{array}{l}\text { Advancement } \\
\text { of knowledge }\end{array}$ & $\begin{array}{l}\text { - To pursue what we haven't known or what } \\
\text { we really want to know }\end{array}$ \\
\hline & $\begin{array}{l}\text { New attempt } \\
\text { and discovery } \\
\text { of truth }\end{array}$ & $\begin{array}{l}\text { - To pioneer a new academic field } \\
\text { - To make a new trial of what nobody has } \\
\text { done }\end{array}$ \\
\hline & $\begin{array}{l}\text { Academics' } \\
\text { activity }\end{array}$ & $\begin{array}{l}\text { - An activity to become an expert who has } \\
\text { deeper knowledge in a very specialized } \\
\text { field }\end{array}$ \\
\hline & Experiment & $\begin{array}{l}\text { - To test something by using microscope and } \\
\text { pipette in lab all day }\end{array}$ \\
\hline & $\begin{array}{l}\text { Hypothesis } \\
\text { testing }\end{array}$ & - To collect evidence to prove something \\
\hline & $\begin{array}{l}\text { Data } \\
\text { gathering }\end{array}$ & $\begin{array}{l}\text { - To collect an enormous amount of factual } \\
\text { data }\end{array}$ \\
\hline
\end{tabular}

\begin{tabular}{|c|c|c|}
\hline \multicolumn{3}{|c|}{ End of Undergraduate Research in Week 10} \\
\hline \multirow{5}{*}{ 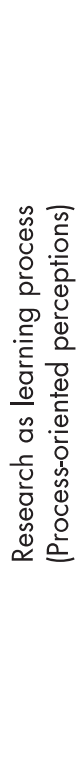 } & Research is... & Verbatim examples \\
\hline & $\begin{array}{l}\text { Self-initiated } \\
\text { activity }\end{array}$ & $\begin{array}{l}\text { - Research is processes of finding out the } \\
\text { truth, which is driven by your inquiring } \\
\text { mind. } \\
\text { - Research is undertaken on our own } \\
\text { initiative. }\end{array}$ \\
\hline & $\begin{array}{l}\text { Collective } \\
\text { working } \\
\text { process }\end{array}$ & $\begin{array}{l}\text { - Research is not only individual but also, } \\
\text { more importantly, collaborative work. All } \\
\text { need to work together for attaining their } \\
\text { shared goal. }\end{array}$ \\
\hline & $\begin{array}{l}\text { Knowledge } \\
\text { construction } \\
\text { process }\end{array}$ & $\begin{array}{l}\text { - Research includes the processes of } \\
\text { integrating a variety of data into analysis. } \\
\text { - Research includes a process of specifying } \\
\text { the principle underlying the extensive data. }\end{array}$ \\
\hline & $\begin{array}{l}\text { Learning } \\
\text { activity }\end{array}$ & $\begin{array}{l}\text { - Research is a sort of daily activity of } \\
\text { learning in that we attempt to reveal what } \\
\text { we want to know. } \\
\text { - Research includes analyzing data and } \\
\text { interpreting the reality which is similar to } \\
\text { learning in everyday class. }\end{array}$ \\
\hline
\end{tabular}

(based on Imafuku et al. 2015)

synthesis of knowledge, active participation, and collaborative and reflective learning.

As this study describes only 14 Japanese medical students' experiences in undergraduate research, the pedagogical im- plications may be limited. However, the significance of this study lies in the fact that it was undertaken as an initial investigation to gain a better understanding of Japanese medical students' actual research experiences. The findings in relation to the qualitative changes in students' perceptions of research and approaches to learning through research experience can be a springboard for further exploration and rigorous assessment of students' learning through undergraduate research.

\section{Future Developments}

Although most Japanese medical schools still have an outcome-oriented view of undergraduate research, the emphasis of students' research activity has been shifting gradually to research processes as a learning opportunity since the late 1990s and early 2000s (e.g., Yamamoto and Matsuyama 1995). Specifically, Imafuku et al. (2015) imply that undergraduate research can further enhance students' deeper approaches to learning and cultivate the fundamental skills necessary to become lifelong learners. This view echoes Kuh's (2008) notion that undergraduate research promotes students' deep learning. Furthermore, working with a faculty member on a research project has been regarded as a high-impact practice that represents enriching educational experiences in the U.S. (National Survey of Student Engagement 2015; Kuh 2008). Therefore, given the context of current Japanese higher education, undergraduate research can be an effective approach to training undergraduates as more active/self-directed learners.

The following points need to be taken into account when adopting undergraduate research as an educational practice in Japan. Undergraduate research in Japanese medical education does not appear to be typically carried out based on learning theories and models. For future development of undergraduate research in Japan, drawing on a robust framework for curriculum and assessment design can be essential to identifying tutors' and students' roles appropriate to the course. For instance, the model of the nature of undergraduate research and inquiry (Healey and Jenkins 2009) provides some ideas on how faculty members can shape students' learning through research and allows for well-defined educational purposes of a research course. A framework for development of research skills (Willison and O'Regan 2007) allows the faculty to define their own roles to suit the level of student autonomy in a given context.

From our pedagogical experiences, inter-university collaboration in undergraduate research can be considered an effective way to enhance students' learning. For instance, after the web conference with Kagawa University, the students 
reflected that they could learn about "research" meaningfully through robust data analysis, insightful discussions with each other, and hearing intelligible academic presentations. As a next step, offering students an opportunity to conduct a collaborative research project with students from other universities might be a pedagogical strategy to enhance students' learning through research.

Gifu University is now planning to introduce an interdisciplinary undergraduate research course in general education for first-year students. This course will enable students from different faculties (education, regional studies, medicine, engineering, and applied biological sciences) to work together on a research project and to freely select a research theme of interest, regardless of their majors. We are expecting this interdisciplinary feature to create diversity in student learning and promote a strong foundation for lifelong learning, including enhancing students' holistic problem-solving skills along with interpersonal communication skills and intrinsic motivation toward learning.

Currently in Japan, society is demanding the ability to deal with complexity and uncertainty related to globalization, an aging population, and ramifications of the information society. Undergraduate research is a new way to engage students in meaningful learning to meet these societal demands. We suggest that application of a pedagogical framework for curriculum and assessment design, inter-university collaboration, and interdisciplinarity can be the key to future development of undergraduate research in Japan.

\section{Acknowledgements}

We gratefully acknowledge the contributions of students and staff at the Medical Education Development Center at Gifu University and Professor Hiroki Okada and Dr. Katsumi Nishiya at the Medical Education Center at Kagawa University for their contribution to a web conference on medical education research. This work was supported by JSPS KAKENHI Grant-in-Aid for Young Scientists (B) Number 26860345.

\section{References}

Association of Japanese Medical Colleges (AJMC). 2014. Japanese Medical Education. Tokyo: AJMC.

Barr, Robert B., and John Tagg. 1995. "From Teaching to Learning: A New Paradigm for Undergraduate Education." Change November/December: 13-25. doi: 10.1080/00091383.1995.10544672.

Central Council for Education. 2012. "Aratana Mirai wo Kizukutameno Daigaku Kyouiku no Shitsuteki Tenkan ni Mukete (in Japanese)." Tokyo: The Ministry of Education, Culture, Sports, Science and Technology. Accessed 15 Oct, 2015. http://www.mext.go.jp/component/b_menu/shingi/toushin/_icsFiles/ afieldfile/2012/10/04/1325048_1.pdf.
Healey, Mick, and Alan Jenkins. 2009. Developing Undergraduate Research and Inquiry. York: The Higher Education Academy. Accessed October 20, 2015. https://www.heacademy.ac.uk/sites/default/files/developingundergraduate_final.pdf

Imafuku, Rintaro. 2012. “Japanese First-Year PBL Students' Learning Processes: A Classroom Discourse Analysis." In Problem-Based Learning in Clinical Education: The Next Generation, edited by Susan Bridges, Colman McGrath, and Tara L. Whitehill, 153-170. Dordrecht: Springer. doi: 10.1007/978-94-007-2515-7_10.

Imafuku, Rintaro, Ryuta Kataoka, Mitsuori Mayahara, Hisayoshi Suzuki, and Takuya Saiki. 2014. "Students' Experiences in Interdisciplinary ProblemBased Learning: A Discourse Analysis of Group Interaction." Interdisciplinary Journal of Problem-Based Learning 8(2): 1-18. doi: 10.7771/1541-5015.1388.

Imafuku, Rintaro, Takuya Saiki, Chihiro Kawakami, and Yasuyuki Suzuki. 2015. "How Do Students' Perceptions of Research and Approaches to Learning Change in Undergraduate Research?" International Journal of Medical Education 6: 47-55.

Kitazawa, Takeshi, Masahiro Nagai, and Jun Ueno. 2008. "Effects of E-Learning System in Blended Learning Environments: Exploring the Relationship between Motivational Beliefs and Self-Regulated Learning Strategies (in Japanese)." Japan Journal of Educational Technology 32(3): 305314.

Kuh, George D. 2008. High-Impact Educational Practices: What They Are, Who Has Access to Them, and Why They Matter. Washington DC: Association of American Colleges and Universities.

Kuwabara, Norimitsu, Miu Yamashita, Yee Keolamau, and David Kurahara. 2015. "The Evolution of the Japanese Medical Education System: A Historical Perspective." Hawai'i Journal of Medicine and Public Health 74(3): 96-100.

Laidlaw, Anita, Jim Aiton, Julie Struthers, and Simon Guild. 2012. "Developing Research Skills in Medical Students: AMEE Guide No. 69." Medical Teacher 34(9): E754-771.

Mori, Hideki. 1991. "About Learning in a Laboratory (in Japanese)." Medical Education (Japan) 22(5): 282

National Survey of Student Engagement (NSSE). 2007. Experiences That Matter: Student Learning and Success. Bloomington, IN: Indiana University School of Education. Accessed January 28, 2016. http://nsse.indiana.edu/ nsse_2007_annual_report/

National Survey of Student Engagement (NSSE). 2015. Engagement Insights: Survey Findings on the Quality of Undergraduate Education. Bloomington, IN. Indiana University School of Education. Accessed January 28, 2016. http:// nsse.indiana.edu/html/annual_results.cfm

Nishiya, Katsumi, Kazunori Sumitani, and Hiroki Okada. 2014. "Trial of Flipped Classroom on Medical Education (in Japanese)." Journal of Higher Education and Research Kagawa University 11: 107-112.

Ohtsuki, Masatsugu, and Toshikazu Matsui. 2014. "Large-Scale Team-Based Learning for Interprofessional Education in Medical and Health Sciences." Medical Teacher 36(5): 452-453. doi: 10.3109/0142159x.2014.909018.

Shigeta, Katsusuke. 2014. "Flipped Classroom: Educational Reform Utilizing Information Technology (in Japanese)." Journal of Information Processing and Management 56(10): 677-684. 
Suzuki, Yasuyuki, Trevor Gibbs, and Kazuhiko Fujisaki. 2008. "Medical Education in Japan: A Challenge to the Healthcare System." Medical Teacher 30(9-10): 846-850. doi: 10.1080/01421590802298207.

The University of Tokyo. 2007. Zenkoku Daigakusei Choosa: The National Survey of University Student (in Japanese). The University of Tokyo Center for Research of University Management and Policy. Accessed October 15, 2015 http://ump.p.u-tokyo.ac.jp/crump/resource/kiso2008_01.pdf.

Willison, John, and Kerry O'Regan. 2007. "Commonly Known, Commonly Not Known, Totally Unknown: A Framework for Students Becoming Researchers." Higher Education Research and Development 26(4): 393-409. doi: 10.1080/07294360701658609.

World Federation for Medical Education (WFME). 2012. Basic Medical Education WFME Global Standards for Quality Improvement: The 2012 Revision. Accessed October 20, 2015. http://wfme.org/standards/bme/78-new-version-2012-quality-improvement-in-basic-medical-education-english/file.

Yamamoto, Hiromichi, and Toshitaka Matsuyama. 1995. "Evaluation of the Learning in a Laboratory Program at the Kyushu University School of Medicine (in Japanese)." Medical Education (Japan) 26(4): 239-245.

Yamauchi, Yuhei. 2014. "Changes in Higher Education and the Future of the Learning Commons (in Japanese)." Journal of College and University Libraries 100: $48-52$.

\section{Rintaro Imafuku}

Gifu University, rimafuku@gifu-u.ac.jp

Rintaro Imafuku is an assistant professor in the Medical Education Development Center at Gifu University. He received his PhD in education from the University of Hong Kong in 2013. He is involved in undergraduate research and facilitating problem-based learning in Japanese medical education. His current research focuses on students' interactions and learning in a learner-centered context, professional-identity formation, health communication, and interprofessional education.

Takuya Saiki is an associate professor in the Medical Education Development Center at Gifu University. He received a master of health professions education from Maastricht University and a $P h D$ in general medicine from Nagoya University. He is a general internist and medical-education researcher focusing on faculty development, clinical education and cultural differences in medical education.

Yasuyuki Suzuki is a professor in the Medical Education Development Center at Gifu University. He received his MD/PhD from Gifu University School of Medicine. He is a pediatrician and president of the Japan Society for Medical Education. His current research focuses on problem-based learning, education in pediatrics, and faculty development for health professions educators.

doi: $10.18833 /$ curq/37/1/10 